\title{
The Effect of Residual Swelling after Drying on Internal Bond in OSB
}

\section{Utjecaj trajne promjene debljine zbog bubrenja na čvrstoću raslojavanja OSB drvnih ploča}

\author{
Original scientific paper • Izvorni znanstveni rad \\ Received-prispjelo: 19. 3. 2012. \\ Accepted-prihvaćeno: 4. 9. 2012. \\ UDK: $630 * 812.23 ; 674.816$ \\ doi: $10.5552 /$ drind.2012.1213
}

\begin{abstract}
The study determined the effect of non-recoverable thickness swelling (NTS) on internal bond in oriented strand boards (OSB). The tests were conducted taking into consideration different time variants, ranging from 1 to $70 \mathrm{~h}$, of soaking in water at $20^{\circ} \mathrm{C}$. The analysis of the results recorded for measured non-recoverable thickness swelling indicates that the observed reduction of strength is a result of changes occurring in the core of boards. Moreover, a linear IB/NTS dependence was observed for OSB/3 and OSB/4 of $15 \mathrm{~mm}$ in thickness.
\end{abstract}

Keywords: OSB, thickness swelling, internal bond, non-recoverable swelling

SAŽETAK - U radu je analiziran učinak trajne promjene debljine zbog bubrenja (NTS) na čvrstoću raslojavanja drvnih ploča s orijentiranim iverjem (OSB). Ispitivanja su provedena uzimanjem u obzir vremena natapanja uzoraka u rasponu od 1 do 70 sati u vodi pri temperaturi $20^{\circ} \mathrm{C}$. Analiza rezultata dobivenih za trajne promjene debljine zbog bubrenja pokazuje da je zabilježeno smanjenje čvrstoće posljedica promjena koje se događaju u središtu drvne ploče. Rezultati su pokazali linearnu ovisnost čvrstoće raslojavanja o vrijednosti trajne promjene debljine za ploče $O S B / 3$ i OSB/4 debljine $15 \mathrm{~mm}$.

Ključne riječi: $O S B$ drvne ploče, debljina nakon bubrenja, čvrstoća raslojavanja, trajna promjena debljine ploče

\section{INTRODUCTION \\ 1. UVOD}

A vast majority of wood-based materials (over 90\%) are composites of comminuted wood and a binding agent bonding these comminuted fragments. The degree of comminution has a decisive effect on mechanical properties of the produced material and it determines its price. The greater the degree of combination, the less advantageous are the mechanical properties, but at the same time also the lower is the price of such materials. A lower price results from the fact that inferior quality wood may be used, frequently already comminuted, coming from thinning of waste in forests or from waste wood from other branches of industry. The type of the applied binding agent determines the degree of resistance to external environmental conditions in a given material and defines its applicability in the broadly understood construction business. Binding agents, providing adequate water resistance of wood-based materials, include synthetic resins based on phenol (Andersen and Troughton, 1996; Irle and Bolton, 1988; Amen-Chen et al. 2002), melamine and isocyanate adhesives (Brochmann et al., 2004). Wood-based materials bonded us-

\footnotetext{
${ }^{1}$ Authors are assistants at Faculty of Wood Technology, Poznań University of Life Sciences, 60-627 Poznań, Poland.

${ }^{1}$ Autori su asistenti Fakulteta drvne tehnologije Sveučilišta bioloških znanosti u Poznanju, Poljska.
} 
ing these adhesives, particularly plywood, V100 boards and OSB, are applied wherever, apart from strength, high moisture resistance is also required. Due to their advantageous price, in recent years the value ratio of OSB has been predominant in the construction industry (Hikiert, 2001; Oniśko, 2002), replacing plywood in many applications. However, high mechanical properties of these boards (Brinkmann, 1979; Zhou, 1990; Nishimura et al., 2001; Han et al., 2005) as well as their considerable moisture resistance (Gu et al. 2005; Mirski et al., 2011; Wu, 1999) do not guarantee high linear expansion stability. Changes caused by moisture in linear dimensions of boards result from hygroscopic properties of wood. Linear expansion in OSB subjected to the action of humid air has been investigated in many studies (Wu, 1999; Suchsland, 2000; Lee and Wu, 2002; Mirski, 2007). In practice, much importance is attributed to changes in thickness. Swelling of boards is caused by very many factors, primarily mat quality, including wood species, chip quality, orientation, the number of layers and their weight ratios, type of resin (formulation, amount applied) as well as used hydrophobic agents (Halligan, 1970; Liu and McNatt, 1991; Mirski et al., 2011). In recent years attention has been focused on the effect of the proportion of swelling in individual layers on total swelling in thickness. This contributed to the patenting of optical measurement of changes in thickness proposed by Wang and Winistorfer (2002). It results from studies presented by Wang and Winistorfer (2003) and Wang et al. (2003) that, in case of OSB, the share of swelling in face layers is dominant. The share of swelling in face layers and the core changes with soaking time. Thus after $2 \mathrm{~h}$ soaking it reached $74 \%$ of total swelling, while after 24 it reached only $57 \%$ of total swelling (Wang and Winistorfer, 2003). Changes in thickness of boards related with changes in its moisture content may be divided into two types: recoverable thickness swelling (RTS) and non-recoverable thickness swelling (NTS) (Halligan, 1970; Wu and Suchsland, 1997). Total thickness of the board deformation caused by changes in the moisture content can be divided into two components: RTS, this is the part of the deformation of the board thickness which disappears after drying the sample to the initial conditions, NTS is a strain that remains despite the loss of force (although the initial humidity is restored).

Residual deformations remaining after the wetting process are generally a consequence of damage to the glue lines as a result of stresses formed in the wetted material (Suchsland and $\mathrm{Xu}, 1991$ ).

A measure of glue line quality in wood-based materials, with the exception of veneer-based boards, such as PB, MDF and OSB, is established by the determination of internal bond (Dai et al., 2008). This method of quality appraisal for glue lines in OSB subjected to wetting and drying processes was presented in their study by $\mathrm{Wu}$ and Piao (1999). They showed that IB in boards subjected to the process of wetting or soaking is proportional to residual deformations. The above mentioned authors conditioned boards, dried at $105{ }^{\circ} \mathrm{C}$, to a specific moisture content or soaked them for a specific time (from $1 \mathrm{~h}$ to $24 \mathrm{~h}$ ), and then dried them again at $105^{\circ} \mathrm{C}$. The differences in thickness between the absolutely dry state before the wetting process and after this process were considered to be NTS. However, it seems that drying under such harsh conditions already causes a certain degradation of the glue lines. Thus the aim of this study was to state whether the previously observed dependence might also be observed, in a situation in which, after the soaking process, samples were led to initial moisture content in the process of the free drying process. Thus the insight into the behaviour of soaked and dried boards could be significant in practice.

\section{MATERIAL AND METHODS}

\section{MATERIJAL I METODE}

Tests were conducted on two types of OSB produced on the commercial scale for the applications in the construction industry, i.e. OSB/4 of 8,15 and 22 $\mathrm{mm}$ in thickness, and OSB/3 of $15 \mathrm{~mm}$ in thickness. Moreover, both types of boards were manufactured from pine (Pinus sylvestris) chips and resinated with pMDI in the core and with MUPF resin in face layers. An enhanced load-bearing capacity of OSB/4 as a rule results from the application of higher resination rates in their manufacture. The basic properties of the tested boards are presented in Tab. 1. All tested boards, irrespective of their type or thickness, exhibited a similar value of swelling in thickness after $24 \mathrm{~h}$ soaking in water. Moreover, all the tested boards were characterised by considerable internal bond and bending strength. In turn, while OSB/4 of $8 \mathrm{~mm}$ in thickness exhibits an over 2-fold higher moisture resistance, measured by the V100 tests, than required by the standard EN 300 $\left(0.17 \mathrm{~N} / \mathrm{mm}^{2}\right)$, already OSB/4 of $22 \mathrm{~mm}$ does not meet the requirements of this standard $\left(0.13 \mathrm{~N} / \mathrm{mm}^{2}\right)$. Moreover, $\mathrm{OSB} / 3$ is characterised by a considerable moisture resistance, even higher than that of OSB/4 with identical thickness.

In order to determine the effect of drying temperature on changes in board properties it was decided to run tests of internal bond with soaked and later dried samples (drying was conducted at different temperatures - see below). For this purpose, a total of 160 samples of $50 \times 50 \mathrm{~mm}^{2}$ were prepared from $15 \mathrm{~mm} \mathrm{OSB} / 4$, and they were soaked in water at a temperature of $20^{\circ}$ $\pm 1{ }^{\circ} \mathrm{C}$. Soaking time of $46 \mathrm{~h}$ was considered sufficient to provide a high degree of saturation with water. After the soaking process, samples were divided into 8 sets, for which different variants of drying temperatures were adopted, i.e. $40{ }^{\circ} \mathrm{C}, 60^{\circ} \mathrm{C}, 75^{\circ} \mathrm{C}, 90{ }^{\circ} \mathrm{C}, 105^{\circ} \mathrm{C}$, $130{ }^{\circ} \mathrm{C}, 160{ }^{\circ} \mathrm{C}$ and $200{ }^{\circ} \mathrm{C}$. After constant mass was reached and after cooling to ambient temperature, their internal bond was determined in accordance with the standard EN 319, which was adopted as an index of board structure damage.

To determine the effect of soaking time on the behaviour of the glue line in each type of the tested OSB, a total of 140 samples of $50 \times 50 \mathrm{~mm}^{2}$ were prepared. A point was marked (at diagonal crossing) on each 
....... Mirski, Majka, Dziurka: The Effect of Residual Swelling after Drying on Internal...

Table 1 Properties of tested commercial boards

Tablica 1. Obilježja komercijalnih ploča upotrijebljenih u eksperimentu

\begin{tabular}{|c|c|c|c|c|}
\hline \multirow{3}{*}{ Property / Obilježje } & \multicolumn{4}{|c|}{ Thickness, mm / Debljina, $\mathrm{mm}$} \\
\hline & \multicolumn{3}{|c|}{$\mathrm{OSB} / 4$} & $\mathrm{OSB} / 3$ \\
\hline & 8 & 15 & 22 & 15 \\
\hline Density $\rho, \mathrm{kg} / \mathrm{m}^{3} /$ gustoća $\rho, \mathrm{kg} / \mathrm{m}^{3}$ & $700^{f}(40)$ & $670(40)$ & $670(25)$ & $645(30)$ \\
\hline Swelling $\mathrm{G}_{t}, \% /$ bubrenje $G_{t}, \%$ & $8.4(0.9)$ & $8.7(0.9)$ & $8.9(1.1)$ & $8.9(1.1)$ \\
\hline Modulus of rupture ${ }^{\mathrm{c}}$ MOR II , N/mm² / modul loma MOR II , N/mm² & $42.9(7.2)$ & $35.1(5.4)$ & $45.0(2.82)$ & $33.3(4.65)$ \\
\hline Modulus of rupture ${ }^{\mathrm{c}} \mathrm{MOR} \perp, \mathrm{N} / \mathrm{mm}^{2} /$ modul loma $M O R \perp, N / \mathrm{mm}^{2}$ & $29.2(1.6)$ & $23.1(1.9)$ & $23.4(1.36)$ & $23.0(2.33)$ \\
\hline $\begin{array}{l}\text { Modulus of elasticity }{ }^{\mathrm{c}} \mathrm{MOE} \mathrm{II}, \mathrm{N} / \mathrm{mm}^{2} \\
\text { modul elastičnosti MOE } \mathrm{I}, \mathrm{N} / \mathrm{mm}^{2}\end{array}$ & $6150(540)$ & $5950(500)$ & $7820(620)$ & $5860(470)$ \\
\hline $\begin{array}{l}\text { Modulus of elasticity }{ }^{\mathrm{c}} \mathrm{MOE} \perp, \mathrm{N} / \mathrm{mm}^{2} \\
\text { modul elastičnosti MOE } \perp, \mathrm{N} / \mathrm{mm}^{2}\end{array}$ & $3580(280)$ & $3540(220)$ & $3710(190)$ & $3420(240)$ \\
\hline Internal bond ${ }^{\mathrm{d}} \mathrm{IB}, \mathrm{N} / \mathrm{mm}^{2}$ / čvrstoća raslojavanja IB, $\mathrm{N} / \mathrm{mm}^{2}$ & $1.11(0.10)$ & $0.84(0.11)$ & $0.78(0.05)$ & $0.65(0.09)$ \\
\hline $\mathrm{V} 100^{\mathrm{e}}, \mathrm{N} / \mathrm{mm}^{2}$ & $0.37(0.03)$ & $0.15(0.01)$ & $0.11(0.01)$ & $0.20(0.01)$ \\
\hline
\end{tabular}

${ }^{\mathrm{a}}$ according to EN $323 ;{ }^{\mathrm{b}}$ according to EN $317 ;{ }^{\mathrm{c}}$ according to EN $310 ;{ }^{\mathrm{d}}$ according to EN $319 ;{ }^{\mathrm{e}}$ according to EN $1087-1 ;{ }^{\mathrm{f}}$ mean value, in parentheses standard deviation

sample, where sample thickness was measured every time. Thus prepared samples together with the control samples were then conditioned in a chamber at a constant temperature and humidity $\left(20 \pm 1{ }^{\circ} \mathrm{C}\right.$ and $30 \% \pm$ $5 \% \mathrm{RH}$ ) for approx. 2 months. It was assumed that this period was sufficient for all the samples to reach identical moisture content at the entire cross-section. Dimensions and weight of each sample were measured and, using control samples, initial moisture content was determined. MC was determined using the gravimetric drier method for each type of boards; however, due to the statistically non-significant differences, moisture content of $5.80 \%$ was assumed as a base moisture content for all board types. Conditioned samples were then soaked in water at $20 \pm 1^{\circ} \mathrm{C}$ for the period specified in the schedule (from 1 to $70 \mathrm{~h}$ ). After the specified time, samples were gently dried using blotting paper and weighed, their thickness was measured to determine the dependence of swelling on absorbability. After this stage, the samples were again conditioned under identical conditions. Periodically weight of randomly selected samples was determined in order to establish their moisture content. The process was repeated until it could be assumed that all the samples reached the moisture content similar to the base one. The samples were then weighed, their thickness was measured and they were subjected to the internal bond test.

NTS was assumed to be the relative change in thickness (1):

where:

$$
N T S=\frac{t_{x}-t_{0}}{t_{0}}
$$

$t_{\mathrm{x}}$ - sample thickness after soaking and conditioning / debljina uzorka nakon natapanja i kondicioniranja,

$\mathrm{t}_{0}$ - sample thickness before the soaking process / debljina uzorka prije postupka natapanja,

while a reduction of internal bond was defined as:

where:

$$
\Delta I B=\frac{I B_{0}-I B_{x}}{I B_{0}} 100 \%
$$

$I B_{0}$ - board strength before soaking / čvrstoća raslojavanja prije natapanja,
$I B_{\mathrm{x}}$ - board strength after soaking and conditioning / čvrstoća raslojavanja nakon natapanja i kondicioniranja.

Moreover, it was decided to approximate results of measurements using a $3^{\text {rd }}$ order polynomial (3),

$$
\begin{aligned}
\hat{y}= & b_{0}+b_{1} x_{1}+b_{2} x_{2}+b_{3} x_{1}^{2}+b_{4} x_{2}^{2}+b_{5} x_{1} x_{2} \\
& +b_{6} x_{1}^{3}+b_{7} x_{2}^{3}+b_{8} x_{1}^{2} x_{2}+b_{9} x_{1} x_{2}^{2}
\end{aligned}
$$

applying an acknowledged technique of response surface methodology (RMS) (Box and Draper, 2007). Polynomial coefficients were determined using the least square method.

Board thickness in the adopted polynomial, i.e. 8 , 15 and $22 \mathrm{~mm}$, was decided to be the first independent variable $\zeta_{1}$, while the second independent variable $\zeta_{2}$ was assumed to be the time of board soaking in water, i.e. $0,1,2,4,6,10,14,18,22,30,38,46,54,62$ and 70 $\mathrm{h}$ However, in order to develop a model variable $\zeta_{1}$ was reduced to $x_{1}$ according to equation (4) and $\zeta_{2}$ to $x_{2}$ according to equation (5):

$$
\begin{gathered}
x_{1}=\left(\xi_{1}-15\right) / 7 \\
x_{2}=\xi_{2} / 70
\end{gathered}
$$

The degree of fit of the model to empirical data is presented in Fig. 1. It results from the presented data that the assumed model showed a very high degree of fit, since for all the analysed dependencies its $R^{2}$ value was greater than 0.98 .

\section{RESULTS AND DISCUSSION} 3. REZULTATI I RASPRAVA

Internal bond of boards soaked in water for $46 \mathrm{~h}$ and then dried at different temperatures is presented in Fig. 2.

It may be concluded from the presented data that the range of occurring changes may be described by two equations of regression curves, characterized by high values of fit indexes $R^{2}$. The first of them describes changes occurring in the glue line in the temperature range of $40-90^{\circ} \mathrm{C}$, and the other in the range of 105 
(a)

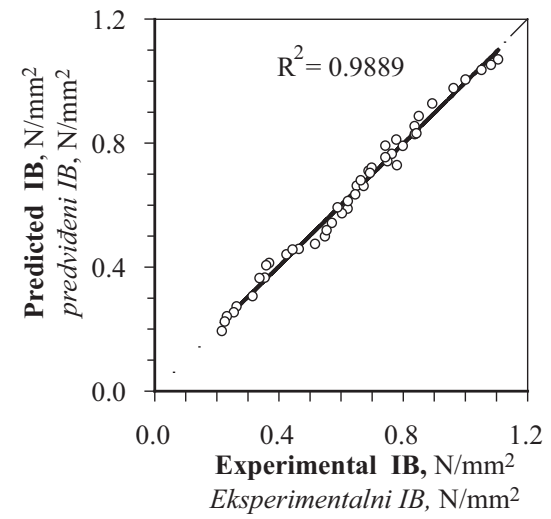

(b)

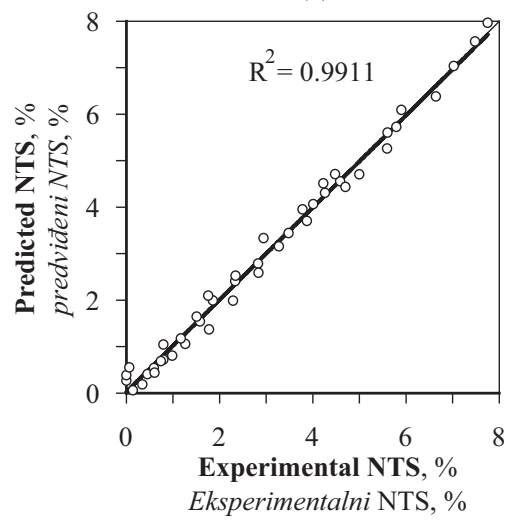

(c)

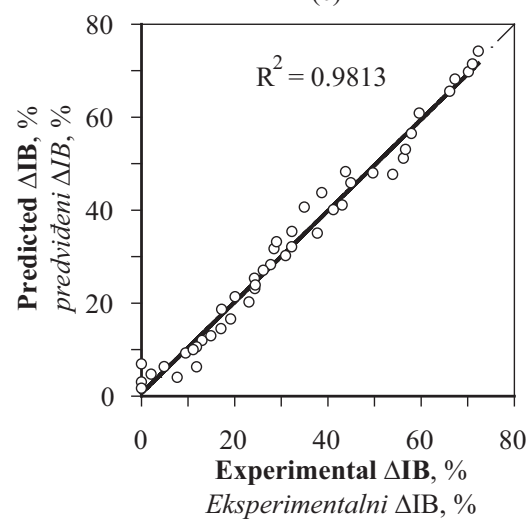

Figure 1 Experimental vs. predicted responses of the models as compared with ideal responses

Slika 1. Korelacija između eksperimentalnih i modelom predviđenih vrijednosti trajne promjene debljine ploča

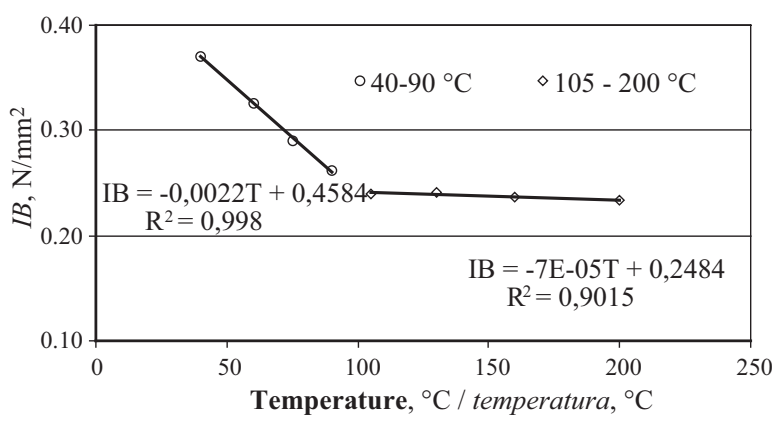

Figure 2 The effect of drying temperature of $\mathrm{OSB} / 4$ soaked for $48 \mathrm{~h}$ in cold water on internal bond

Slika 2. Utjecaj temperature sušenja na čvrstoću raslojavanja OSB/4 ploča nakon 48-satnog natapanja u hladnoj vodi

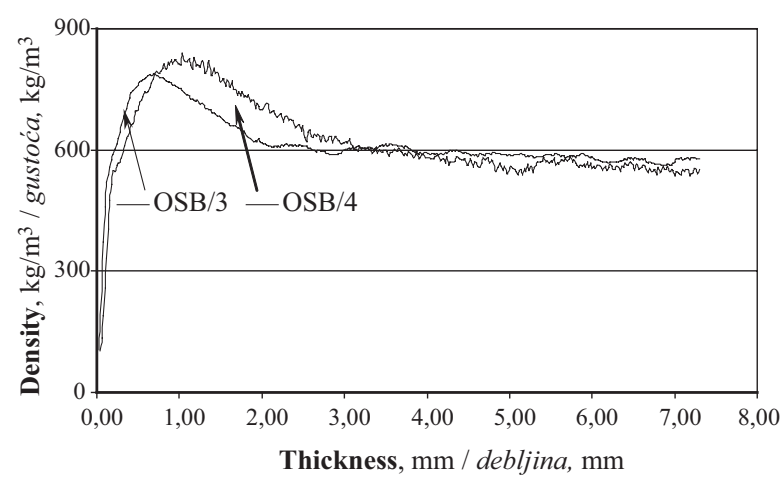

Figure 3 The density profile of tested commercial boards of $15 \mathrm{~mm}$ in thickness

Slika 3. Profil gustoće komercijalnih ploča debljine $15 \mathrm{~mm}$ upotrijebljenih u istraživanju
$-200{ }^{\circ} \mathrm{C}$. In the range of $40-90{ }^{\circ} \mathrm{C}$, we may observe an intensive drop in internal bond, while over $105^{\circ} \mathrm{C}$ these changes are much milder. For presented dependencies, a common point for both straight lines is approx. $100^{\circ} \mathrm{C}$. Thus, it results from the presented dependencies that after exceeding the temperature of $100{ }^{\circ} \mathrm{C}$, no significant changes are observed in properties of OSB, this being a consequence of an additional factor, i.e. drying temperature. Thus a well-known regularity is confirmed that the milder are the conditions causing changes (reduction) of moisture content in wood or wood-based materials, the smaller is the degradation of their mechanical properties.

The dependence of swelling on absorbability is presented in the form of a linear regression equation $T S$ $=a_{0}+a_{1} W A$, giving in Table 2 the values of coefficients for this equations as well as the fit index $r^{2}$. Table 2 also presents the values of absorbability and swelling recorded for tested boards after $70 \mathrm{~h}$ soaking in water.

As it could have been expected, there is a highly linear dependence of swelling in thickness and the amount of water absorbed by OSB. Such an assumption was presented not only by Wu and Piao (1999), but also by Mirski et al. (2011). Although it does not reflect the actual course of sorption and its effect in the form of linear expansion, it still seems to sufficiently well describe the occurring changes.

Moreover, as it results from the data presented in Tab. 2, the greatest increment in thickness, caused by the absorption of an identical amount of water, was found for OSB/4 of $8 \mathrm{~mm}$ in thickness, while it was the lowest in $2 \mathrm{~mm} \mathrm{OSB} / 4$. In turn, $15 \mathrm{~mm} \mathrm{OSB} / 3$ has a

Table 2 Regression results on TS-WA relationship for OSB/3 with a linear model $\left(T S=a_{0}+a_{1} . W A\right)$

Tablica 2. Rezultati regresijske analize linearne povezanosti bubrenja i apsorpcije vode ploče $\mathrm{OSB} / 3\left(T S=a_{0}+a_{1}\right.$.WA $)$

\begin{tabular}{|c|c|c|c|c|c|}
\hline \multirow{2}{*}{$\begin{array}{c}\text { Regression } \\
\text { coefficients } \\
\text { Koeficijent } \\
\text { regresije }\end{array}$} & \multirow{2}{*}{$\begin{array}{c}\text { Unit } \\
\text { Jedinica }\end{array}$} & \multicolumn{4}{|c|}{ Numerical value / Numerička vrijednost } \\
\cline { 3 - 5 } & & 8 & 15 & 22 & 15 \\
\cline { 3 - 5 } & $\%$ & -0.7505 & -1.8564 & -2.6324 & OSB/3 \\
\hline$a_{0}$ & $\% / \%$ & 0.3855 & 0.3532 & 0.3229 & 0.3333 \\
\hline Slope, $\mathrm{a}_{1}$ & - & 0.9954 & 0.9926 & 0.9884 & 0.9939 \\
\hline$R^{2}$ & $\%$ & 14.00 & 19.44 & 15.43 & 21.74 \\
\hline$T S$ & $\%$ & 39.23 & 60.57 & 54.88 & 71.64 \\
\hline$W A$ & & &
\end{tabular}




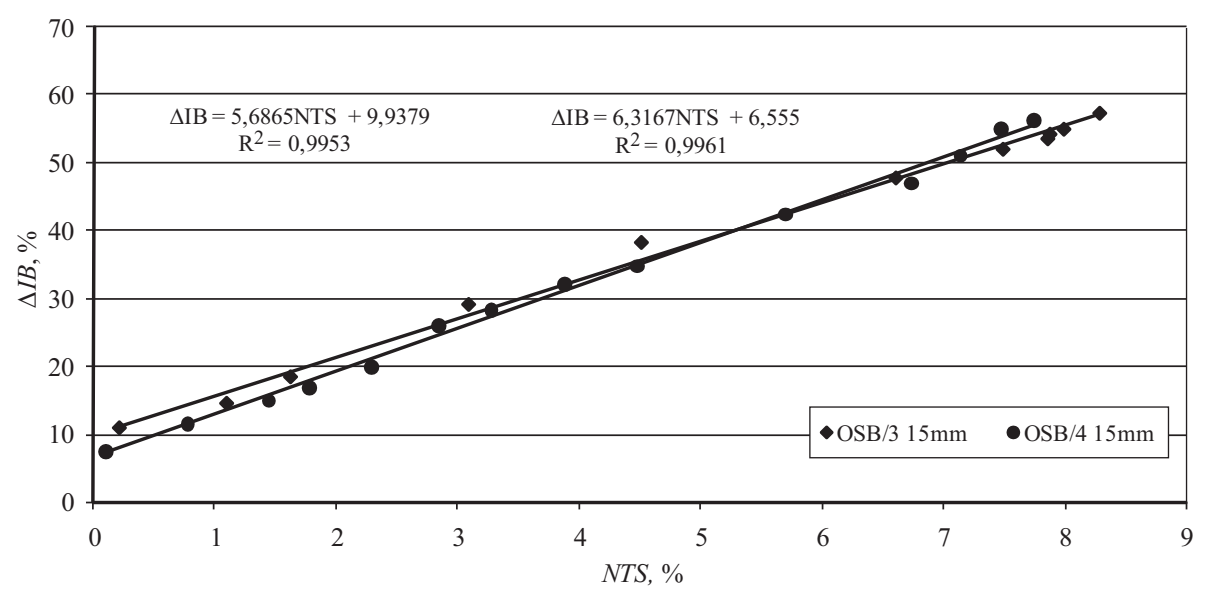

Figure 4 Reduction of internal bond in OSB $/ 3$ and $\mathrm{OSB} / 4$ boards depending on the residual deformations Slika 4. Smanjenje čvrstoće raslojavanja ploča OSB/3 I OSB/4 u ovisnosti o trajnoj promjeni njihove debljine

similar coefficient of changes in thickness as $22 \mathrm{~mm}$ $\mathrm{OSB} / 4$. Such behaviour of boards confirms earlier reports that the swelling ratio in OSB is related to their density (Rice and Carey, 1978; Mirski et al. 2011).

As it could have been expected, the greatest swelling in thickness after $70 \mathrm{~h}$ soaking was found for $\mathrm{OSB} / 3$. The swelling value for this board is $21.74 \%$, but it is still by only $2.5 \%$ higher than swelling in $\mathrm{OSB} / 4$ of identical thickness. It seems that swelling of $15 \mathrm{~mm} \mathrm{OSB} / 4$ is relatively high both in relation to $\mathrm{OSB} / 3$ and the other OSB/4 variants. While the observed high swelling in OSB/3 may be explained by a lower resination ratio at the manufacture of such boards, high swelling in OSB/4 of identical thickness comes as a surprise. However, it results from the data presented in Tab. 1 that physical and mechanical properties of these boards are practically identical, except for internal bond and strength after the boiling test. Higher IB values for OSB/4 may probably be attributed to the higher average density and the distribution of density at the board cross-section. As it results from Fig. 3, in case of this board there is a greater density of chips in the face layer.

Extension of the zone of lower densities in $\mathrm{OSB} / 3$ also results in a markedly higher absorbability. In turn, the recorded high strength of OSB/3 after the boiling test causes a situation when at such a long soaking time the effects of density and moisture resistance begin to be balanced. The above statement is also confirmed by the fact that a reduction of internal bond, which may be described with a good approximation with a linear equation in the function of residual deformations for both boards, is very similar (Fig. 4).

Values of residual deformations observed for $\mathrm{OSB} / 4$ are presented in Fig. 5.

It results from these data that short-term soaking, of max. $5 \mathrm{~h}$, causes only slight non-recoverable thickness swelling, of only $1 \%$, in OSB $/ 4$, and it is irrespective of their thickness. With the time of board exposure to cold water, the volume of thickness swelling increases and, in the analyzed case, it starts to depend more markedly on board thickness. Up to $24 \mathrm{~h}$ these differences are still slight, but with an extension of soaking time, it becomes evident that the greatest non-recoverable deformations are found in $15 \mathrm{~mm}$ boards. High resistance of $8 \mathrm{~mm}$ boards is probably a consequence of both high density and the stated moisture resistance determined by the boiling test (Table 1). Such a situation is also indicated by low absorbability of these boards, determined after $70 \mathrm{~h}$ soaking in cold water. In turn, $22 \mathrm{~mm} \mathrm{OSB} / 4$, despite its much lower density, potentially suggesting higher capacity to absorb water, and a relatively low moisture resistance, possibly reflected in the values of swelling, exhibits both low values of non-recoverable deformations and swelling (Table 2). The low swelling ratio and low values of non-recoverable deformations indicate that the tested board is characterized by a high level of chip hydrophobicity. Such an effect may be obtained by an increase in the amount of hydrophobic additives and/or thanks to the application of higher resination rates. It is a well-known fact that commonly used paraffin emulsions effectively reduce the hydrophilic character of

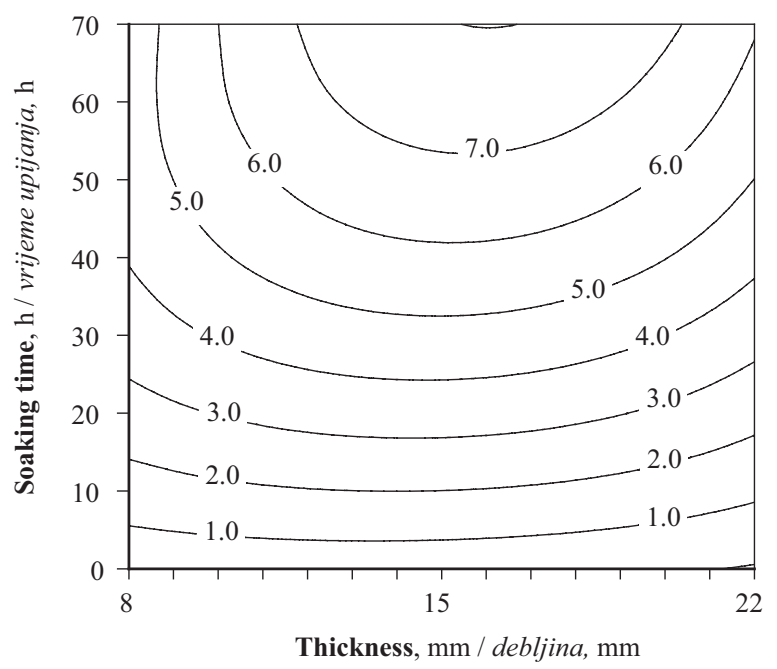

Figure 5 Expected residual deformations after drying depending on soaking time and thickness of OSB/4

Slika 5. Očekivane vrijednosti trajne promjene debljine ploča nakon sušenja u ovisnosti o vremenu natapanja i debljini ploča 


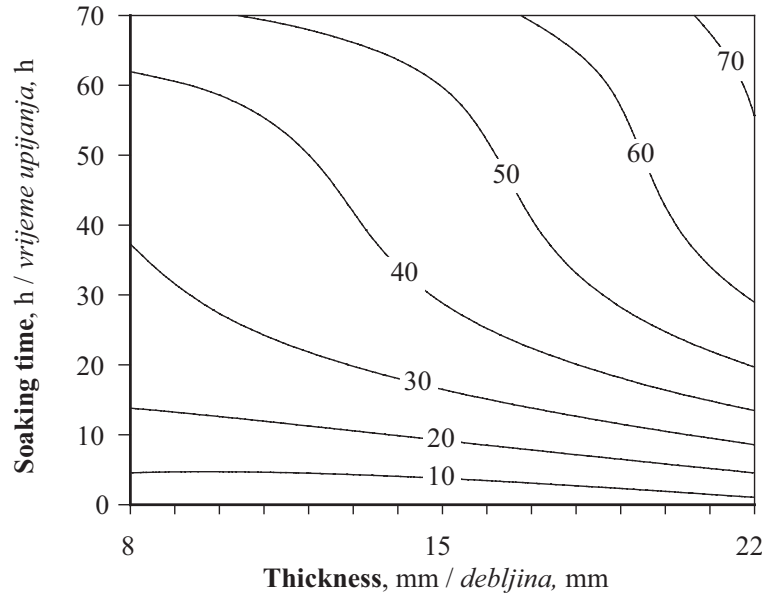

Figure 6 Expected relative reduction of internal bond depending on soaking time and thickness of OSB/4 Slika 6. Očekivane vrijednosti smanjenja čvrstoće raslojavanja u ovisnosti o vremenu natapanja i debljini ploča

materials during their exposure to cold water, whereas in hot water they are dissolved.

The effect of soaking time of OSB/4 on their internal bond is presented in Fig. 6 .

As it results from the provided data, in case of a short-term soaking of boards, irrespective of their thickness, we may observe a permanent reduction of internal bond, amounting to $10-20 \%$. With an extension of soaking time the degree of degradation increases, and it is much greater for thicker boards. During IB strength testing, most samples were destroyed in the core and it was irrespective of board thickness. Only in several cases, rupture occurred at the interface of the core and the face layers. Thus in the scheduled testing period, even if the observed linear expansion pertained mainly to face layers, potentially suggesting that the greatest degradation of the glue line took place in those layers, the core was still the weakest point in terms of its internal bond. In the opinion of the authors of this study, the markedly lower density of the core in OSB results in a situation where penetration of water is faster in this layer and hence stresses are first formed there, causing glue line degradation. Although linear expansion (swelling) in this layer is not as marked as in the face layers, as suggested in the study by Wang and Winistorfer (2003), it seems that the observed reduction of strength and at the same time degradation of the glue line are mostly related to the core. Obviously, we may not reject a hypothesis that the percentages of destruction changes in face layers are greater. However, their high initial strength results in a situation where for the adopted testing period the core still remains the weakest part of the board. In this respect suggestions of the authors seem to confirm the results of a still unpublished paper, from which it results that a significant reduction of strength in the face layers of OSB occurs only after 4 - 5 cycles of the V313 test.

The relationship between residual deformation in OSB/4 of various thicknesses and a permanent reduction of internal bond is presented in Fig. 7.

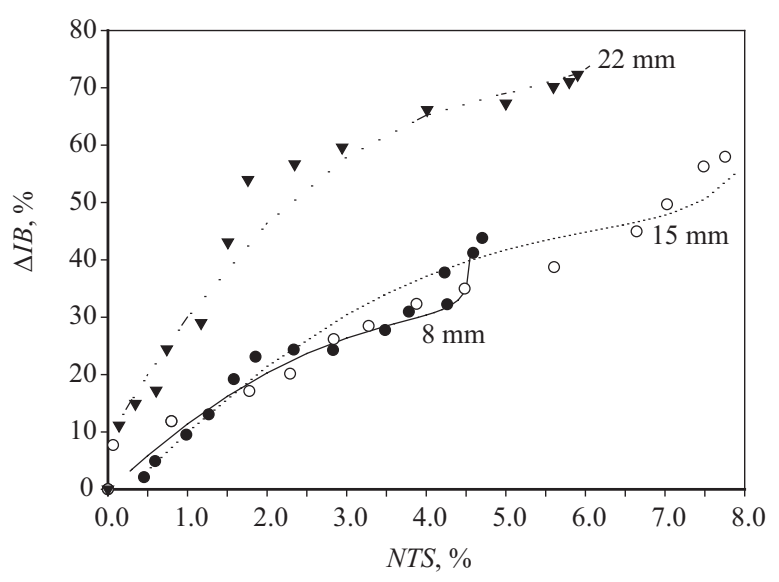

Figure 7 Dependence between residual deformation of $\mathrm{OSB} / 4$ with various thicknesses and permanent deterioration of internal bond

Slika 7. Ovisnost trajne promjene čvrstoće raslojavanja i trajne promjene debljine ploče za ploče različitih debljina

As it results from these data, the constructed mathematical model based on equation (3) illustrates well the process of changes occurring in tested boards. Only in case of $15 \mathrm{~mm}$ boards, the character of occurring changes may be described by a linear equation, as presented in Fig. 4. It results from this model that for each board thickness there is a certain boundary value of residual deformation, which, when exceeded, results in a dramatic decrease of strength. Thus, for example, in case of $8 \mathrm{~mm}$ boards, this effect may be observed after exceeding $4 \%$ NTS, while in $15 \mathrm{~mm}$ boards it may be observed after exceeding approx. $7 \%$. Such behavior of boards may be expected, since long-term board soaking causes their destruction exceeding the capacity of boards to return to the original thickness.

\section{CONCLUSION}

\section{ZAKLJUČAK}

As a result of tests conducted, it was found that the conditions, under which previously soaked boards are dried, have a significant effect on their residual strength. As it could have been expected, the milder the board drying conditions (lower temperature, higher humidity), the smaller their reduction of strength. The boundary temperature, after which such a significant deterioration of strength is no longer observed, is the boiling point of water. However, at this temperature, the strength of boards is already by over $40 \%$ lower than that found after drying at $40{ }^{\circ} \mathrm{C}$.

Moreover, it results from the tests conducted that the soaking time significantly influences the strength of OSB in terms of their internal bond. However, shortterm soaking up to approx. $5 \mathrm{~h}$ causes a permanent reduction of strength by only approx. $10-20 \%$, and this is irrespective of board thickness. In turn, a longer soaking time results in a situation where the internal bond is reduced to a greater extent in thicker boards. Thus, the observed decrease in strength after $60 \mathrm{~h}$ soaking in case of $8 \mathrm{~mm}$ boards was approx. $45 \%$, while for $22 \mathrm{~mm}$ boards it exceeded $70 \%$. 
The formed permanent residual deformations, whose volume is strongly connected with the soaking time and drying temperature, within a certain range may be connected linearly with a decrease in internal bond. Except for $15 \mathrm{~mm}$ boards, this pertains mainly to very small values of residual deformations, typically below $2 \%$. However, irrespective of OSB thickness there is a boundary value of NTS, where a significant deterioration of strength is observed.

\section{REFERENCES}

\section{LITERATURA}

1. Andersen, A.W.; Troughton, G.E., 1996: New phenolic formulations for bonding higher moisture kontent OSB panels. For Prod J, 46(10): 72-76.

2. Irle, M.A.; Bolton, A.J., 1988: Physical Aspects of Wood Adhesive Bond Formation with Formaldehyde Based Adhesives. Part II. Binder Physical Properties and Particleboard Durability. Holzforschung 42(1): 150-156 http://dx.doi.org/10.1515/hfsg.1988.42.1.53.

3. Amen-Chen, C.; Riedl, B.; Wang, X.; Roy, Ch., 2002: Softwood bark pyrolysis oil-PF resols. Part 1. Resin synthesis and OSB mechanical properties. Holzforschung 56(2): 167-175 http://dx.doi.org/10.1515/HF.2002.028.

4. Brochmann, J.; Edwardson, C.; Shmulsky, R., 2004: Influence of resin type and flake thickness on properties of OSB. For Prod J 54(3): 51-55.

5. Box, G. E. P.; Draper, N. R., 2007: Response surfaces, mixtures, and ridge analyses. New Jersey. Willey http:// dx.doi.org/10.1002/0470072768.

6. Hikiert, M. A., 2001: Płyty OSB materiałem dla budownictwa. Przem Drzew 3: 3-6.

7. Oniśko, W., 2002: Drewnopochodne materiały budowlane. Przem Drzew 3/6: 3-10.

8. Brinkmann, E., 1979: OSB-Platten, ihre Eigenschaften, Verwendung und Herstellungstechnologie. Oriented structural boards (OSB), their properties, application and manufacture. Holz a. Roh- u. Werkst 37: 139-142 http:// dx.doi.org/10.1007/BF02610844.

9. Zhou, D., 1990: A study of oriented structural board made from hybrid poplar. Physical and mechanical properties of OSB. Holz a. Roh- u. Werkst 48: 293296.

10. Nishimura, T.; Ansell, M. P.; Ando, N., 2001: The relationship between the arrangement of wood strands at the surface of OSB and the modulus of rupture determined by image analysis. Wood Sci Tech 35: 555-562 http://dx. doi.org/10.1007/s002260100118.

11. Han, G.; Wu, Q.; Duan, X., 2005: Physical and mechanikal properties of mixed comrind and hardwood oriented strandboard bonded with phenol-formaldehyde resin. For Prod J 55 (10): 28-36.

12. Mirski, R.; Derkowski, A., 2011: Properties of OSB subjected to the boiling test. Acta Sci Pol, Silv Colendar Rat Ind Lignar 11(4).

13. Gu, H.; Wang, S.; Neimsuwan, T.; Wang, S., 2005: Comparison study of thickness swell performance of commercial oriented strandboard flooring products. For Prod J 55(12): 239-245.
14. Wu, Q., 1999: In-plane dimensional stability of oriented strand panel: effect of processing variables. Wood Fiber Sci 31(1): 28-44.

15. Wu, Q.; Lee, J. N., 2002: Thicknes swelling of oriented stramdboard under long-term cyclic humidity exposure condition. Wood Fiber Sci 34(1): 125-139.

16. Wu, Q., 1999: In-plane dimensional stability of oriented strandboard panel: Effect of processing variables. Wood Fiber Sci 31(1): 28-40.

17. Suchsland, O., 2000: Modeling the linear expansion of wod composities. Wood Fiber Sci 32(4): 540-544.

18. Mirski, R.; Derkowski, A.; Łęcka, J., 2007: The effect of ambient conditions on dimensional stability of OSB/3. Ann. Warsaw Agricult. Univ.-SGGW, For Wood Technol 62: $40-48$

19. Halligan, A. F., 1970: A review of thickness swelling in particleboard. Wood Sci Technol 4: 301-312 http://dx.doi. org/10.1007/BF00386406.

20. Liu, J. Y.; McNatt, J. D., 1991: Thickness swelling and density variation in aspen flakeboard. Wood Sci Technol 25: 73-82 http://dx.doi.org/10.1007/BF00195558.

21. Rice, J. T.; Carey, R. H., 1978. Wood density and board composition effects on phenolic resin-bonded flakeboard. For Prod J 28(4): 21-28.

22. Mirski, R.; Dziurka, D.; Derkowski, A., 2011: Dynamics of changes in thickness of commercial OSB/3 subjected to soaking. Wood Research 56(3): 403-412.

23. Wang, S.; Winistorfer, P. M., 2002: Process and system for determination of layer TS of wood composites. U. S. Patent 6,396,590.

24. Wang, S.; Winistorfer, P. M., 2003: An optical technique for determination of layer thickness swell of MDF and OSB. For Prod J 53(9): 64-79.

25. Wang, S., Gu, H.; Neimsuwan, T.; Wang, S., 2003: Layer thickness swell and related properties of commercial OSB products: A comparative Study. In: Proc. of the $37^{\text {th }}$ International Wood Composite Materials Symp., Apr. 7-10, Washington State Univ., Pullman WA. pp. 65-76.

26. Wu, Q.; Suchsland, O., 1997: Effect of moisture on the flexural properties of comercial oriented strandboard. Wood Fiber Sci 29(1): 47-57.

27. Suchsland, O.; Xu, H., 1991: Model analysis of flakeboard variables. For Prod J 41 (11/12): 55-60.

28. Dai, Ch.; Yu, Ch.; Jin, J., 2008: Theoretical modeling of bonding characteristic and performance of wood composites. Part IV. Internal bond strength. Wood Fiber Sci 40(2): 146-160.

\section{Corresponding address:}

Assistant RADOSLAV MIRSKI, Ph.D.

Poznań University of Life Sciences

Faculty of Wood Technology

Department of Wood-Based Materials

Wojska Polskiego 38/42

60-627 Poznań, POLAND

e-mail: rmirski@up.poznan.pl 